\title{
Religious perception and the education of attention
}

\author{
Tim Ingold
}

University of Aberdeen

As a long-time advocate of the ecological approach to perception, and an implacable opponent of cognitivism in all its forms (Ingold 2000), I am much in sympathy with the argument of this paper. I agree that the cognitive science of religion, with its stress on explaining the tenacity of apparently irrational beliefs (Boyer 2000), completely misses the point. For in sourcing religion to compendia of beliefs about the world, and about what may or may not exist in it, cognitive theorists interpose an ontological barrier between the mind in which such beliefs are to be found and the world to which they pertain which flies in the face of the very existential commitment and the passion that infuses it - or in a word, the faith that surely lies at the foundation of religious sensibility. Religion, as theologian Peter Candler (2006: 30-40) has put it, is enshrined in a grammar not or representation but of participation, in a recognition that knowledge and understanding are not superimposed on the world from the outside, in the attempt to explain or interpret it, but grow from the inside, from the crucible of our involved participation in a world in the continual becoming of which our lives and feelings are necessarily enmeshed.

In the cognitive science of religion, religious intuitions couched in the performative grammar of participation are refracted through the distorting lens of a grammar of representation that denies, a priori, the very commitment on which participation depends. The inevitable result is to recast these intuitions as a spectrum of beliefs in 'spiritual' entities which, if they existed in fact, would defy obvious principles of physical and biological causation. Thus cognitivism, 
having already corrupted what it sets out to explain, is locked in a circularity of its own making. As Barrett puts it, theories that invoke belief to explain experiential differences are merely begging the question. We should rather start from perceptual experience itself, and James Gibson's (1979) theory of direct perception, with its emphasis on the skilled engagement of the perceiver with the furnishings and textures of a richly structured environment, offers a way to do so.

Nonetheless, though I remain an enthusiast, I am no longer sure whether Gibson's approach takes us quite far enough. What I like about it is the focus on attention. Learning to perceive, for Gibson, is learning to attend - to notice, to discriminate, to pick things out. The skilled perceiver is an active explorer of his or her surroundings, not a passive recipient of stimuli that have then to be processed by the intellect in order to arrive at a hypothetical picture of what is 'out there'. Yet there is a contradiction at the heart of the approach, for while the perceiver is described as moving, dynamic and exploratory, the world to be perceived appears to have been already laid out, like a furnished room awaiting its occupants or a stage with all its scenery waiting for the actors to make their entry. The environment is there, for Gibson (1979: 139): its objects afford what they do because of what they are, irrespective of the presence of any creature that might happen upon them.

Yet religious experience, I would contend, does not lie in the perception of a ready-made world, nor does religious practice lie in mastering the skills for engaging with its constituents. It lies rather in the perception of a world that is itself continually coming into being both around and along with the perceiver him- or herself. It is because such perception is intrinsic to the process of the world's coming-into-being that it is also imaginative, rather than opposed to imagination as Gibson thought (Ingold 2012: 6-7). And while we may endorse 
Gibson's apt characterisation of perceptual learning as an 'education of attention' (Gibson 1979: 254), I would argue that the education to which novices lay themselves open, in religious practice, is just the opposite of what Gibson had in mind. Recall that the word attendre, in French, means 'to wait', and that even in English, to attend to things or persons carries connotations of looking after them, doing their bidding, and following what they do. In this regard, attention abides with a world that is not ready made but always incipient, on the cusp.

Thus, rather than world's lying in wait for the perceiver, it is the perceiver who waits upon the world. As the philosopher Jan Masschelein (2010) has observed, this kind of education is not an instilling of meaning and value into the person, but a 'leading out' of the person along a line of movement. That is what education (from the Latin $e x=$ 'out' + ducere $=$ 'to lead') literally means. To be thus thrust out, into a world that has yet to reveal its hand, is unsettling. It implies not the mastery of the skilled practitioner but the submission of one who - being out of position, or ex-posed - is at the mercy of what transpires. As indigenous people versed in the way of being that westerners call 'animism' tell us, only a fool would presume to know what the world will bring. The wise man, or woman, looks, listens and waits for things to reveal themselves for what they are. Along these ways of perception lie experience, understandings and transformations of the self. Indeed animism, contrary to what Barrett suggests, is not really about ascribing intentionality to non-human entities, as though for humans and non-humans alike, the executive cast of action followed the reflective cast of thought. It is rather about attending to other beings, in perception and action, as they attend to you - or, in a word, about corresponding with them (Ingold 2013: 105-8). As with animism in particular so religion in general, I would argue, is about neither belief nor direct perception 
but mutual attention or correspondence. As the philosopher Michel Serres (1995: 48) puts it, the opposite of religion is not atheism or lack of belief but negligence.

Apart from these qualifications, only one thing really jarred in my reading of this paper, and that is the author's insistence on a distinction between 'insiders' and 'outsiders, and between insider and outsider experiences. This strikes me as rigid and insensitive to context, and somewhat out of kilter with the overall tenor of the argument, which would put any such division in doubt. Moreover it tends to obscure the much more fundamental distinction, between inside and outside ways of knowing. As I have shown, it is by eliding this distinction that cognitive theorists miscast religious intuitions as irrational beliefs. Finally, I did wonder about the stress on the scientific search for explanations of religious experience. This does seem to put science and religion on opposite sides of a fence, with science doing the explaining and religion the 'object' to be explained. It seems to me that this division is untenable. What if the source of religious experience lies in those pre-objective commitments to the world in which we find our being, and which in turn underwrite the very possibility of science?

\section{References}

Boyer, P. (2000). Functional origins of religious concepts: ontological and strategic selection in evolved minds. Journal of the Royal Anthropological Institute 6, 195-214.

Candler. P. M. Jr. (2006). Theology, rhetoric, manuduction, or reading scripture together on the path to God. Grand Rapids, MI: William B. Eerdmans.

Gibson, J. J. (1979). The Ecological Approach to Visual Perception. Boston: Houghton Mifflin. 
Ingold,T. (2000). The Perception of the Environment: Essays on Livelihood, Dwelling and Skill. London: Routledge.

Ingold, T. (2012). Introduction. In Imagining Landscapes: Past, Present and Future, eds. M. Janowski and T. Ingold. Farnham: Ashgate, pp. 1-18.

Ingold, T. (2013). Making: Anthropology, Archaeology, Art and Architecture. Abingdon: Routledge.

Masschelein, J. (2010). E-ducating the gaze: the idea of a poor pedagogy. Ethics and Education 5: 43-53.

Serres, M. (1995). The natural contract (trans. E. MacArthur and W. Paulson). Ann Arbor, MI: University of Michigan Press. 